Hortigüela Alcalá, D., Fernández Río, J., Castejón Oliva, J. \& Pérez Pueyo, A. (2017). Formative assessment, work regulation, organization, engagement, tracking and attendance in Spanish Universities. Revista Electrónica Interuniversitaria de Formación del Profesorado, 20 (3), 49-63. DOI: http://dx.doi.org/10.6018/reifop.20.3.268681

\title{
Formative assessment, work regulation, organization, engagement, tracking and attendance in Spanish Universities
}

\author{
David Hortigüela Alcalá( ${ }^{(1)}$, Javier Fernández Río( ${ }^{(2)}$, Javier Castejón Oliva ${ }^{(3)}$, Ángel Pérez \\ Pueyo $^{(4)}$ \\ (1) Universidad de Burgos, ${ }^{(2)}$ Universidad de Oviedo, ${ }^{(3)}$ Universidad Autónoma de Madrid, ${ }^{(4)}$ \\ Universidad de León.
}

\section{Abstract}

The Assessment Systems Scale, a 34-item questionnaire, was proven a robust, reliable and valid instrument to evaluate assessment procedures at the university level. However, the sample used to validate it was rather small, and proper validation of instruments requires testing on multiple independent samples. The current study evaluated the reliability and the validity of a reduced version, 23 items, of the instrument, as well as its interactions. Study 1 examined the validity and reliability of the reduced version of the Assessment System Scale in a large sample of Spanish university students. 3.428 students and 52 teachers from 17 different universities across Spain agreed to participate. Results showed a 3 -factor structure and high internal consistency $(\alpha=.835)$. In Study 2 descriptive and inferential statistics showed that formative assessment significantly linked students' work regulation and organization, engagement, tracking and attendance. Students who participated in formative assessment understood how necessary was class attendance, because it favoured engagement and, as a consequence, better regulation and content integration throughout the teaching-learning process. A significant relationship was found between peer review and more effective feedback to improve task understanding. Moreover, the definition of clear assessment criteria correlated positively with individual or group work registration. Different levels of self-regulated work was found depending on the students' university degree. It seems necessary to implement formative assessment systems with tools and procedures that ensure an alternative to more traditional methodological approaches.

\section{Keywords}

Higher education; self-regulation, learning, assessment; formative assessment.

\section{Contacto:}

David Hortigüela Alcalá, dhortiguela@ubu.es, Facultad de Educación.C/ Villadiego s/n. 09001. Burgos Este estudio se ha llevado a cabo dentro del proyecto de I+D+i: "Las competencias docentes en la formación inicial del profesorado de educación física”. Convocatoria de noviembre de 2013 del Programa Estatal de Investigación, Desarrollo e Innovación Orientada a los Retos de la Sociedad, en el marco del Plan Estatal de Investigación Científica y Técnica y de Innovación 2013-2016. Referencia: EDU 2013-42024-R. Duración: 3 años (2014-2016). 


\section{Evaluación formativa, regulación del trabajo, organización, compromiso, seguimiento y asistencia en Universidades Españolas}

\section{Resumen}

La Escala del Sistema de Evaluación, un cuestionario de 34 items, ha sido probada como un instrumento robusto, fiable y válido para analizar los procedimientos de evaluación a nivel universitario. No obstante, la muestra empleada para validarla fue ciertamente pequeña y una adecuada validación de un instrumento requiere que sea probado en múltiples muestras independientes. Los estudios que se presentan evaluaron la fiabilidad y la validez de la versión reducida de solo 32 items, así como sus interacciones. El estudio 1 determinó la validez y la fiabilidad de la versión reducida de la Escala del Sistema de Evaluación en el contexto de una muestra amplia de estudiantes universitarios. 3428 estudiantes y 52 profesores de 17 universidades diferentes de la geografía española accedieron a participar. Los resultados mostraron una estructura de 3 factores y una alta consistencia interna ( $\alpha=$ .835). En el estudio 2 estadísticas descriptivas e inferenciales mostraron que la evaluación formativa estableció conexiones significativas entre la organización y regulación del trabajo, el compromiso, el seguimiento y la asistencia. Los estudiantes que participaron en sistemas de evaluación formativa comprendieron cómo de necesaria es la asistencia a clase, porque favorece un mayor compromiso y, como consecuencia, una mejor regulación y monitorización del contenido a lo largo del proceso de enseñanza-aprendizaje. Se encontró una relación significativa entre la evaluación entre iguales y un feedback más efectivo para la mejora en la comprensión de las tareas. Además, la delimitación de criterios claros de evaluación correlacionó positivamente con el registro de trabajo individual o en grupo. Se encontró un nivel de autorregulación del trabajo diferente en función de la titulación estudiada. Se concluye que para la aplicación de sistemas de evaluación formativa es preciso utilizar procedimientos útiles y sistemáticos que verdaderamente garanticen una alternativa a sistemas metodológicos más tradicionales.

\section{Palabras clave}

Educación superior; auto-regulación; aprendizaje; evaluación; evaluación formativa.

\section{Introduction}

In the context of a global market, students must learn to self-regulate and take responsibility for their learning to address the frequent changes of our society. Teachers should design contexts that encourage students to play a more active role. This change means moving the focus of the educational process from the teachers to the students (Weymer, 2002). To achieve quality learning at the university level, two curricular elements are particularly relevant: (a) a more diversified and participatory learning approach to overcome the traditional "banking teaching processes" (Biggs, 1999); and (b) assessment procedures not focused on the final grade, but promoting more student engagement and self-regulation. This means switching from an "exam culture" to an "assessment culture" (Dochy, Segers \& Dierick, 2002).

The methodology-assessment interrelationship is essential from the perspective of quality university learning (Biggs, 1999). Teachers must learn how to generate knowledge in their 
academic activity. The priority should be to engage students in active and participatory processes (Millis, 2010; Mulongo, 2013). Such participation enhances knowledge integration to truly incorporate information (Huber, 2008). Regarding assessment, teachers should consider how students learn in order to achieve higher student self-regulation and efficiency (Boud, Cohen \& Sampson, 2001; Hortigüela \& Pérez-Pueyo, 2015; Hortigüela \& Pérez-Pueyo, 2016a; Hortigüela, Pérez-Pueyo \& López-Pastor, 2015). This goal makes assessment a more complex procedure, because it is much more than giving a grade. It means providing information for students to take on more responsibility. The key is to verify what students have learned during the process using tools that could help them selfregulate their learning (Duncan \& Buskirk-Cohen, 2011). This is the perspective required in todays universities, and included in the guidelines of the European Higher Education Area (EHEA).

Formative assessment is a systematic, continuous activity through which teachers assess the quality of the students' outcomes, using the information obtained, to promote and improve learning (Boud, 2000). Previous studies revealed a connection between formative assessment and the achievement of deep learning (Lorente \& Kirk, 2013; Stull, Varnum, Ducette, Schiller \& Bernacki, 2011). Students perceived that their active participation in the assessment process helped them achieve learning outcomes, because their interests were considered and they could reflect on the proposed goals and achieved outcomes. Hence, considering the goals of both parties (teachers and students) better outcomes were achieved (Furnham, Batey \& Martin, 2011). Teachers use formative assessment to adjust goals, critically review plans, programs, methods and resources, guide students, and provide feedback (Urda \& Ramocki, 2015; Hortigüela \& Pérez-Pueyo, 2016b). All this can lead to greater student engagement in learning regulation, becoming active agents in their learning process, adapting the tasks to the proposed goals and acquiring a better criterion for self- or other-assessment (Cassidy, 2011; Schunk \& Zimmerman, 2008). The use of different strategies in formative assessment (i.e. self-assessment and peer-assessment) has shown that students regulate their learning when they are allowed to use them and receive information from their peers (Duncan \& Buskirk-Cohen, 2011; Hortigüela, Pérez-Pueyo \& Abella, 2015a).

Students' perceptions and engagement is a significant element in formative assessment. Various studies have confirmed how important is for teachers to know their students' perceptions and assess their behaviors related to assessment and work performance (García-Sanz, 2014; Struyven, Dochy \& Janssens, 2005; Hortigüela, Abella, Delgado \& Ausín, 2016; Hortigüela \& Pérez-Pueyo, 2016c; Hortigüela, Pérez-Pueyo \& Abella, 2015b). Formative assessment has been used in all areas, but always from the perspective of learning (Black, Harrison, Lee, Marshall \& Wiliam, 2003). Teacher-student feedback has always been an important element to research (Sadler, 2010). Work regulation and organization, the way students plan and organize each task (including the organization of their study), practical strategies such as tutoring, individual and collaborative work, instruments that provide knowledge, and logs are important. However, there is a need to assess whether or not there is a connection between work regulation and organization and engagement and tracking; that is, the way students participate in their teaching-learning process, being an active part of it. Teacher assessment can affect students, encouraging their autonomy and climate. There is a need to explore in what ways these impact work regulation and organization. On the other hand, class attendance is usually required in most courses/programmes. However, there is a need to better understand its connections with students' perceptions. Finally, there is a direct connection between class attendance and academic performance (Schunk \& Zimmerman, 2008); although in many cases, it is considered a requirement rather than a criterion. When students attend class, they become 
aware of elements that are part of the class, since they are addressed and discussed by the teacher, who gives more importance to some parts and verifies whether the students have understood them (Charles \& Del Río, 2013; Chen \& Lin, 2008). However, there are discrepancies regarding this point of view. Kelly (2012) showed that mandatory class attendance did not guarantee better learning outcomes, because the key is the purpose of attendance, the relationship between the student's and the teacher's expectations, and by whom and how the learning is regulated.

The present study seeks to build on the existing literature in this area. Although the initial development and validation study of the Assessment System Scale (Castejón, Santos \& Palacios, 2015) found robust reliability and validity, the sample size was quite small $(n=155)$. Proper validation of instruments requires testing on multiple independent samples (Stockdale \& Brockett, 2011). Based on the aforementioned, two studies were conducted in the present research project. The goal of study 1 was to examine reliability and validity of the reduced version of the Assessment Systems Scale. The working hypothesis was that it will be a valid and reliable instrument with a three-factor structure. The goal of study 2 was to use the reduced version of the Assessment Systems Scale to measure participants' view of the assessment procedures used in their classes. Three research questions guided this study: RQ1: What are the connections among the three factors of the scale? RQ2: How does class attendance affect self-regulation? and RQ3: What is the influence of student's age, number and contents taught on self-regulation and work engagement?

\section{Method}

Participants were the same in the two studies conducted. In each one, the instrument used for data collection, the procedure followed and the analysis used are fully explained. In the second study, due to the inferential analyzes used, a discussion section is included. This section answered the second goal of the study and the three questions that derived from it. Finally, the conclusions obtained on each of the two studies are also presented.

\section{Participants}

3.428 students ( $56.1 \%$ males, $43.9 \%$ females) and their 52 teachers ( $47.12 \pm 6.83$ years of age; $16.21 \pm 7.32$ years of professional experience) from 17 universities across Spain agreed to participate. $28 \%$ of the participating students were enrolled in year $1,26 \%$ in year $2,19 \%$ in year 3 , and $27 \%$ in year 4 . Their mean age was $21.5 \pm 1.84$ years. No on-line students were included. All participants belonged to Teacher Training Undergraduate Programs, which last four academic years (240 credits). Each subject had 6-9 credits. The Shapiro-Wilks test showed that the sample was normally distributed $(p=.218)$.

\section{Study 1}

Instrument

The Assessment Systems Scale (Castejón, Santos \& Palacios, 2015), a valid and reliable questionnaire designed to assess teachers' assessment procedures at the university level, was used. It is a 34-item instrument grouped in six subscales. A group of eight university experts on formative assessment reduced the number of items to 23. The goal was to develop a specific questionnaire with factors or subscales. All responses ranged from 1 (Not at all) to 5 (Very much). The stem: "In your university classes..." was added to the questionnaire. 


\section{Procedure}

All university teachers belonging to the Network of Formative Assessment (López-Pastor, Castejón, Sicilia, Navarro \& Webb, 2011) who were conducting teacher training courses were contacted. The goal was to select teachers who were actively using formative assessment in their classes and had published works on formative assessment over the last five years. They were asked about their current assessment procedures, confronting this information with the subject's program published on each university's website. An anonymous analysis of these teachers' programs was conducted by six university experts on formative assessment. Programs earning two negative votes were rejected. Consequently, 52 participants were selected, eight were excluded. The goal was to confirm that formative assessment procedures were truly being conducted with the students that were going to participate in the study. All the selected teachers included student engagement processes in their assessment, and they encouraged their students to selfregulate their study, both in and out of the classroom. These students knew from the beginning of the semester how they were going to be evaluated and graded, and what they had to do individually or in groups. At the end of the course, students completed the selected questionnaire. At all times, their anonymity and the confidentiality of their data were ensured.

\section{Statistical analysis}

All analyses were conducted using the SPSS 20.0 statistical package. Exploratory and confirmatory factor analyses were conducted to evaluate the validity of the reduced version of the questionnaire (Table 1). First, an exploratory factor analysis was conducted to assess the internal structure of the reduced version of the questionnaire and determine the factors associated to the variables. Means, standard deviation and item-total correlation were calculated for item analysis. Cronbach's a was calculated to evaluate internal consistency. Barlett's sphericity test (1950) indicated that the items were dependent $(p<.02)$ and the Kaiser-Meyer-Olkin index of sample adequacy was higher than the recommended value of $.50(\mathrm{KMO}=.814)$. A solution of three factors was obtained with a self-value higher than 1. Normalized Varimax was applied to correct and rotate the initial matrix components. It showed that the three-factor structure explained all the variance. The self-value of the first factor explained $41.371 \%$ of variance, the second factor explained $32.669 \%$ of variance and the third factor explained a $25.960 \%$ of variance. Second, a main components confirmatory factor analysis was conducted to assess the factors obtained and their loadings. Several indices were used: Chi-square $\left(x^{2}\right)$, Root Mean Square Error (RMSE), Comparative Fit Index (CFI), and Goodness of Fit Index (GFI). They all produced adequate scores: $x^{2}=148.131$ with 15 degrees of freedom, RMSE $=.067$, values below .05 indicate good fit and up to .08 reasonable errors (Herrero, 2010), CFI .91 , and $\mathrm{GFI}=.90$, both are adequate. Cronbach's a was .835 , higher than .81 which is considered reliable (Corbetta, 2007). Finally, to assess the fit of each of the 23 items selected to their corresponding factors, the regression coefficient was applied through value $t$ associated to each estimate, obtaining a value of 2.16 (scores above 2.23 are considered significant; Balaguer, Guivernau, Duda \& Crespo, 1997) (Table 2). 
Table 1.

Final version of the questionnaire

\begin{tabular}{|l|}
\hline Categoría 1. Organización y regulación del trabajo \\
\hline 1. Se usan instrumentos para registrar el trabajo \\
\hline 2. Se usan tutorías para resolver dudas \\
\hline 3. El profesor delimita el tiempo de trabajo de cada tarea \\
\hline 4. Se utiliza el portafolio \\
\hline 5. Se establecen los criterios de seguimiento \\
\hline 6. El proceso de aprendizaje está pautado \\
\hline 7. Las coevaluaciones y autoevaluaciones son positivas \\
\hline 8. Se establecen plazos para no acumular el trabajo \\
\hline 9. Se realizan procesos de coevaluación \\
\hline Categoría 2. Compromiso y seguimiento \\
\hline 10. Se requiere una participación elevada \\
\hline 11. Se realizan informes en los que se detalla el seguimiento \\
\hline 12. La clase se compromete hacia el trabajo \\
\hline 13. Se emplea una metodología participativa \\
\hline 14. Se realizan variedad de actividades en el proceso \\
\hline 15. Se definen claramente los criterios de organización \\
\hline 16. Se proporciona feedback para fomentar la implicación \\
\hline 17. Es fundamental registrar el trabajo realizado individual o en grupo \\
\hline Categoría 3. Asistencia y evaluación \\
\hline 18. Se requiere de continuidad en la asistencia a clase \\
\hline 19. Se requiere continuidad y seguimiento \\
\hline 20. Se requiere más responsabilidad \\
\hline 21. Se necesita comprender su funcionamiento desde el comienzo \\
\hline 22. La asistencia a clase limita la inseguridad e incertidumbre \\
\hline 23. La asistencia a clase permite mayor seguimiento e implicación \\
\hline
\end{tabular}

Table 2.

Factor loadings and item statistics of the Assessment Systems Scale reduced in study 1.

\begin{tabular}{|l|l|l|l|}
\hline Item & Orig. item\# & Factor & $\mathrm{M}(\mathrm{SD})$ \\
\hline 1.Instruments are used to register the work done & 5 & 0.71 & $3.87(1.21)$ \\
\hline 2. Tutorials are used to solve doubts & 16 & 0.77 & $3.12(1.31)$ \\
\hline 3. The teacher times the deadlines for each task & 2 & 0.81 & $4.03(1.65)$ \\
\hline 4. Portfolios are used & 4 & 0.73 & $3.83(1.35)$ \\
\hline 5. Follow-up criteria are set & 3 & 0.79 & $3.45(1.28)$ \\
\hline 6. The learning process is controlled & 21 & 0.68 & $3.54(1.63)$ \\
\hline 7. Co-assessment and self-assessments are positive & 23 & 0.75 & $4.12(1.83)$ \\
\hline 8. Deadlines are specified to not accumulate work & 19 & 0.78 & $3.52(1.41)$ \\
\hline 9. Peer co-assessment is performed & 20 & 0.84 & $3.89(1.56)$ \\
\hline 10. High engagement is required & 6 & 0.73 & $4.13(1.35)$ \\
\hline 11. Reports are made to reflect the work & 10 & 0.77 & $3.12(1.31)$ \\
\hline 12. The class is committed to work & 12 & 0.80 & $4.33(1.12)$ \\
\hline 13. A participatory methodology is used & 14 & 0.81 & $4.35(1.12)$ \\
\hline 14. A variety of activities are conducted regularly & 18 & 0.76 & $3.85(1.03)$ \\
\hline 15. Work organization patterns are clearly defined & 22 & 0.79 & $3.91(1.15)$ \\
\hline 16. Feedback is provided to promote the involvement & 24 & 0.71 & $4.03(1.61)$ \\
\hline
\end{tabular}




\begin{tabular}{|l|l|l|l|}
\hline $\begin{array}{l}\text { 17. It is essential to record the work performed individually } \\
\text { or in groups }\end{array}$ & 26 & 0.75 & $3.54(1.33)$ \\
\hline $\begin{array}{l}\text { 18. Class attendance is required } \\
\text { 19. Continuity and follow up is required }\end{array}$ & 28 & 0.84 & $3.81(1.47)$ \\
\hline 20. More responsibility is necessary de process from the & 30 & 0.79 & $4.13(1.56)$ \\
\hline $\begin{array}{l}\text { 21. It's necessary to understand de } \\
\text { beginning }\end{array}$ & 31 & 0.80 & $4.07(1.38)$ \\
\hline 22. Class attendance limits the insecurity and uncertainty & 32 & 0.75 & $3.51(1.21)$ \\
\hline 23. Class attendance allows more tracking & 34 & 0.74 & $3.25(1.17)$ \\
\hline
\end{tabular}

\section{Results}

The factor analysis conducted yielded three categories, factors or subscales: Category 1 (C1): Work regulation and organization (Table 3). It assesses how students plan and organize each task, including their study, their practical strategies (i.e., tutoring, individual and collaborative work, instruments that provide knowledge, keeping a log of the activities' quality). Category 2 (C2): Engagement and tracking (Table 4). It addresses how students participate in their teaching-learning process, being an active part of it. Teacher's assessment procedures affect students, encouraging their autonomy and engagement, their negotiation strategies for assessment and grading, and improving the participatory climate. Category 3 (C3): Attendance-based assessment (Table 5). It addresses the degree of required attendance, as well as the students' perceptions of their needs to monitor the subject.

Table 3.

Category C1: Work regulation and Organization.

\begin{tabular}{|l|l|}
\hline \multicolumn{1}{|c|}{ Items } & Definition \\
\hline C1a & Instruments are used to register the work done \\
\hline C1b & Tutorials are used to solve doubts \\
\hline C1C & The teacher times the deadlines for each task \\
\hline C1d & Portfolios are used \\
\hline C1e & Follow-up criteria are set \\
\hline C1f & The learning process is controlled \\
\hline C1g & Co-assessment and self-assessments are positive \\
\hline C1h & Deadlines are specified to not accumulate work \\
\hline C1i & Peer co-assessment is performed \\
\hline
\end{tabular}

Table 4.

Category C2: Engagement and tracking.

\begin{tabular}{|l|l|}
\hline Items & Definition \\
\hline C2a & High engagement is required \\
\hline C2b & Reports are made to reflect the work \\
\hline C2C & The class is committed to work \\
\hline C2d & A participatory methodology is used \\
\hline C2e & A variety of activities are conducted regularly \\
\hline C2f & Work organization patterns are clearly defined \\
\hline C2g & Feedback is provided to promote the involvement \\
\hline C2h & It is essential to record the work performed individually or in groups \\
\hline
\end{tabular}


Table 5.

Category 3 (C3): Attendance-based assessment.

\begin{tabular}{|l|l|}
\hline Items & Definition \\
\hline C3a & Class attendance is required \\
\hline C3b & Continuity and follow up is required \\
\hline C3C & More responsibility is necessary \\
\hline C3d & It's necessary to understand de process from the beginning \\
\hline C3e & Class attendance limits the insecurity and uncertainty \\
\hline C3f & Class attendance allows more tracking \\
\hline
\end{tabular}

\section{Conclusions}

The goal of study 1 was to examine the reliability and the validity of the reduced version of the Assessment Systems Scale. Results have showed that it is a valid and reliable instrument to evaluate assessment procedures at the university level. It also showed adequate internal consistency with three factors or subscales: work regulation and organization, engagement and tracking and attendance-based assessment.

\section{Study 2}

\section{Instrument}

The reduced version of the Assessment Systems Scale was used to assess participants' views of the assessment procedures used in their classes.

\section{Statistical analysis}

Descriptive and inferential analyses were conducted using the SPSS 20.0 statistical package. Correlations, contingency tables, chi-square and ANOVAS were also obtained to gain deeper knowledge on the gathered data.

\section{Results}

\section{Descriptive Analysis}

Means and standard deviation of the three categories were 4.37, 4.15, and 4.45 for $\mathrm{C} 1$ (work regulation and organization), C2 (engagement and tracking), and C3 (attendance-based assessment), respectively. They were all high, over 4 (maximum value $=5$ ). $C_{3}$ (attendancebased evaluation) obtained the highest mean, but there were no significant differences between them (Table 6).

Table 6.

Mean and Standard deviation of each subscale or category

\begin{tabular}{|l|l|l|}
\hline \multicolumn{1}{|c|}{ Subscale/Category } & M & SD \\
\hline Subscale/Category 1 & 4.37 & 1.47 \\
\hline Subscale/Category 2 & 4.15 & 1.25 \\
\hline Subscale/Category 3 & 4.45 & 1.35 \\
\hline
\end{tabular}




\section{Inferential Analysis}

Correlations. Table 7 shows relevant and significant correlations between work regulation and organization and engagement and tracking $\left(r_{3428}=.512, p<.022\right)$ and between work organization and engagement and attendance-based assessment $\left(r_{3428}=.135, p<.004\right)$. The remaining correlations were low, albeit positive.

Table 7.

Pearson Correlations among all Categories.

\begin{tabular}{|l|l|l|l|}
\hline Pairs of categories & $\mathrm{N}$ & $\mathrm{r}$ & $\mathrm{P}$ (2-tailed) \\
\hline Category $1 /$ Category 2 & 3428 & .512 & .022 \\
\hline Category $1 /$ Category 3 & 3428 & .135 & .004 \\
\hline Category 2/Category 3 & 3428 & .146 & .321 \\
\hline
\end{tabular}

Note: Category $1\left(\mathrm{C}_{1}\right)=$ Work regulation and organization; Category $2\left(\mathrm{C}_{2}\right)=$ Engagement and tracking; Category $3\left(\mathrm{C}_{3}\right)=$ Attendance-based assessment. Fuente: Elaboración propia.

The strength of the link between the most representative pairs of items of the three categories was analyzed to determine possible significant connections between the students' responses. A significant relationship was found in three pairs of items. The first pair was "need for attendance" and "student engagement" $\left(\chi^{2}(3428)=97.14, p=.013\right)$. A significant relation was also observed in the positive aspect of co-assessments and selfassessments and the feedback provided in the subjects $\left(\chi^{2}(3428)=78.41, p=.032\right)$. The students' responses also revealed a direct relationship between work organization and the work $\log$ used $\left(\chi^{2}(3428)=62.34, p=.025\right)$. However, the relation between class attendance and the teacher's timing of work deadlines was non-significant $\left(X^{2}(3428)=112.39, p=.311\right)$. In fact, this item, which is part of work regulation and organization scored, very low $(M=3.31)$, reflecting the students' confusion and difficulty to regulate their work when the teacher does not clearly define the deadlines for each task. This seems to reveal the lack of students' tracking of their learning process, which is usually linked to a score-oriented assessment (Table 8).

Table 8.

Relation between Items concerning Student Self-regulation and Class Attendance.

\begin{tabular}{|l|l|l|l|}
\hline Items & $\chi^{2}$ & $d f$ & $P$ \\
\hline Class attendance is required (C3)/ High engagement is required (C2) & 97.14 & 11 & .013 \\
\hline $\begin{array}{l}\text { Co-assessment and self-assessments are positive (C1)/ Feedback is } \\
\text { established to facilitate engagement in the process (C2) }\end{array}$ & 78.41 & 16 & .032 \\
\hline $\begin{array}{l}\text { Work organization patterns must be defined (C2)/ It is essential to record } \\
\text { the work carried out individually or in groups (C2) }\end{array}$ & 62.34 & 11 & .025 \\
\hline $\begin{array}{l}\text { Class attendance allows more tracking (C3)/ The teacher times the } \\
\text { deadlines for each task (C1) }\end{array}$ & 112.39 & 9 & .311 \\
\hline
\end{tabular}

Note: Category $1\left(\mathrm{C}_{1}\right)$ = Work regulation and organization; Category 2 (C2) = Engagement and tracking; Category $3\left(C_{3}\right)=$ Attendance-based assessment.

ANOVA. By weighting the items relating to work regulation and engagement, a new variable called: "Self-regulation and engagement in the process" was created. This dependent variable (Table 9) could be related to independent variables such as students' age, contents 
taught, and class size. The following age ranges were formed: a) 18-20; b) 21-23; and c) over 23. With regard to the content, the following subjects were used: a) Physical Education; $b$ ) School curriculum; and c) Specific Experimental Didactics. Finally, regarding class size, three categories were established: a) 20-50; b) 51-70; and c) more than 70. A post-hoc Bonferroni analysis was performed to determine significant differences among groups. They were found only for the independent variable "content taught" between Physical Education and Specific Experimental Didactics. Students enrolled in Physical Education programs obtained higher values in self-regulation and engagement.

Table 9.

ANOVA (Bonferroni) of three Independent Variables on the Dependent Variable Self-regulation and Work Engagement

\begin{tabular}{|l|l|l|l|}
\hline Self-regulation and work engagement & $F$ & $d f$ & $p$ \\
\hline Student's age & 96.12 & 1 & .335 \\
\hline Contents taught & 73.21 & 2 & $.014^{*}$ \\
\hline Class size & 61.53 & 1 & .261 \\
\hline
\end{tabular}

Note: ${ }^{*} p<.05$ between Physical Education $(M=4.39)$ and Specific Experimental Didactics ( $M$ $=3.22$. .

\section{Discussion}

The goal of study 2 was to use the reduced version of the Assessment Systems Scale to measure participants' views of the assessment procedures used in their classes. Results showed that formative assessment significantly linked students' work regulation and organization, engagement, tracking and attendance.

Regarding the first research question, what is the relationship among the three factors of the scale?, our results showed a positive connection between work regulation and organization and students' engagement and tracking. When students are more autonomous planning their work, they engage more. Other studies (Shen, McCaughtry, Martin \& Fahlman, 2009) reported significant correlations between students' autonomy in task performance, greater motivation to practice, and a higher perception of achievement. Stephens and Winterbottom (2010) found a direct connection between a learning log used by the students during class tasks and greater reflection on their learning, which also led to greater engagement. One of the elements that students positively valued in work organization is the log, either individual or collective. Teachers promote student engagement in the activities when they use instruments that help students take notes, review, and be aware of the work done and the work that remains to be done (Furnham, Batey \& Martin, 2011). One of the most striking findings was that the participating students valued the deadlines marked by the teacher to a lesser extent than other items such as "high engagement is required" or "co-assessment and self-assessment are positive". Previous research has showed that college students value deadlines (Kinne, Haserbank \& Coffey, 2014), but our participants considered that student-centered assessment procedures were more important.

Regarding work regulation and organization, our results showed that formative assessment encouraged students to organize their study and participate in the tasks requested by the teachers. This is in line with findings from Huber (2008), but this author highlighted the 
need to define teachers' criteria beforehand. The concept of work regulation and organization has to do with the teaching approach (Boud, Cohen \& Sampson, 2001), since it is linked to assessment and vice versa. Nevertheless, our results showed that students valued "being more aware of their work" in peer assessment procedures. Students praised this process, but this does not mean that they were able to take advantage of all the potential that it can provide.

Regarding engagement and tracking, our results showed that students were more likely to learn when they were more engaged, and teachers performed follow-ups. Students tend to show more interest in their learning when they are engaged in the tasks, either because they obtain better grades or because they verify that those learnings have a practical application (Palacios \& López-Pastor, 2013; Gynnild, Holstad \& Myrhaug, 2008). Results indicated that students who showed more motivation in the process also perceived greater responsibility.

Regarding the second hypothesis, how does student's class attendance affect selfregulation? our results showed that many students perceived "class attendance" as one of the most valued factors to monitor the class throughout the course. Items linked to class attendance correlated significantly with students' work regulation and planning. These results are in line with those supporting that class attendance improves learning (Charles \& Del Río, 2013; Chen \& Lin, 2008) because students think that understanding what is taught it is useful, a more detailed monitoring of the subject can be made, and self-control and task organization improve. However, these authors also indicated the need to adopt methodologies that do not require class attendance. Underlining factors like the incompatibility between subjects' timetables and students' work schedules and the distance between their homes and the university campus should be considered. On the other hand, our study showed how the students appreciated class attendance only when taks' delivery was clearly defined. Results also showed that participatory assessment, which shares some features with formative assessment, is difficult to conduct without the students attending class.

Regarding the third research question, what is the influence of student's age, number of students enrolled and contents taught on self-regulation and work engagement? significant differences were obtained only in the type of content taught: Physical Education achieved the highest rating. Bignold (2013) found that motor experiences can generate greater student involvement in their own learning, only when participatory and student-centred strategies are used, which focus on integration and not performance. Finally, class size had no impact on regulation and engagement. Previous research has showed that the number of students in class does not justify their lower engagement in learning (Carnero, Burn \& Hagger, 2010). However, our results highlighted the importance of using more regulated feedback when the class has more students. Previous studies have showed that first year undergraduate students have a harder time regulating their work and adjusting to the university organizational framework (Siebett \& Walsh, 2013).

\section{Conclusions}

First, students who participated in formative assessment understand how necessary class attendance is because it favors greater engagement and, as a consequence, better content regulation throughout the teaching-learning process. Students acknowledged that the use of co-assessment and self-assessment favored task engagement, and helped them become 
aware of the work done. Finally, age and number of students per class were not related to higher self-regulation and task engagement. However, significant differences were found between Physical Education and Specific Experimental Didactics, with the former being the one that obtained higher ratings in work regulation and engagement. This reflects the difference between disciplines in relation to self-regulation and work engagement. It is important to consider that many factors influence formative and shared assessment, and these processes must be adapted to fit the specific context. If teachers want their students to be autonomous and responsible it is necessary to develop active and participatory methodologies, involving them in the process of teaching and learning.

The main contribution of the study was to validate a reduced version of the Assessment System Scale. It is a significant contribution to the existing literature on formative and shared assessment, since it brings an improved assessment instrument for researchers. It showed how students can improve their work regulation and organization, engagement, tracking and attendance. Results may be of interest to university teachers who want to generate involvement and autonomy in their classes. It is a starting point in higher education to transform traditional methodologies into open and participatory approaches. This investigation presents some limitations. Firstly, students' perception was measured at the end of the process. Likewise, only formative assessment and initial teacher training were assessed. Future research should compare students' perceptions after experiencing different assessment methods, and contrast their initial and final perceptions to determine possible changes, and extend these experiences to other university degrees.

\section{References}

Balaguer, I., Guivernau, M., Duda, J. L., \& Crespo, M. (1997). Análisis de la validez de constructo y de la validez predictiva del cuestionario de clima motivacional percibido en el deporte (PMCSQ-2) con tenistas españoles de competición. Revista de Psicología del Deporte, 11, 41-57.

Biggs, J. B. (1999). Teaching for quality learning at University. Buckingham, UK: Open University Press.

Bignold, W. J. (2013). Developing School Students' Identity and Engagement through Lifestyle Sports: A Case Study of Unicycling. Sport, Education and Society, 18(2), 184-189.

Black, P., Harrison, C., Lee, C., Marshall, B., \& Wiliam, D. (2003). Assessment for learning. Putting it into practice. Maidenhead: Open University Press.

Boud, D. (2000). Sustainable assessment: Rethinking assessment for the learning society. Studies in Continuing Education, 22(2), 151-67.

Boud, D., Cohen, R., \& Sampson, J. (2001). Peer learning in higher education: Learning from and with each other. London: Kogan.

Carnero, T., Burn, K., \& Hagger, H. (2010). Making sense of learning to teach: Learners in context. Research Papers in Education, 25(1), 73-91.

Cassidy, S. (2011). Self-regulated learning in higher education: Identifying key component processes. Studies in Higher Education, 36(8), 989-1000. 
Castejón, F. J., Santos, M., \& Palacios, A. (2015). Cuestionario sobre metodología y evaluación en formación inicial en Educación Física. Revista Internacional de Medicina y Ciencias de la Actividad Física y el Deporte, 15(58), 245-267.

Charles, R., \& Del Río, J. (2013). Making research methods relevant for students: An illustrative study on low self-control, class attendance, and student performance. Journal of Criminal Justice Education, 24(4), 495-516.

Chen, J., \& Lin, T. (2008). Class attendance and exam performance: A randomized experiment. The Journal of Economic Education, 39(33), 213-227.

Dochy, F., Segers, M., \& Dierick, S. (2002). Nuevas vías de aprendizaje y enseñanza y sus consecuencias: una era de evaluación. Red Estatal de Docencia Universitaria, 2(2), 13-29.

Duncan, T., \& Buskirk-Cohen, A. (2011). Exploring learner-centered assessment: A crossdisciplinary approach. International Journal of Teaching and Learning in Higher Education, 23(2), 246-259.

Corbetta, P. (2007). Metodologías y técnicas de investigación social. Madrid: McGrawHill.

Furnham, A., Batey, M., \& Martin, N. (2011). How would you like to be evaluated? The correlates of students' preferences for assessment methods. Personality and Individual Differences, 50, 259-263.

García-Sanz, M. P. (2014). La evaluación de competencias en Educación Superior mediante rúbricas: un caso práctico. Revista Electrónica Interuniversitaria de Formación del Profesorado, 17(1), 87-106.

Gynnild, V., Holstad, A., \& Myrhaug, D. (2008). Identifying and promoting self-regulated learning in higher education: Roles and responsibilities of student tutors. Mentoring $y$ Tutoring: Partnership in Learning, 16(2), 147-161.

Hortigüela, D., \& Pérez-Pueyo, A., \& Abella, V. (2015a). Percepciones del alumnado sobre la evaluación formativa: Contraste de grupos de inicio y final de carrera. REDU. Revista de Docencia Universitaria, 13(3), 12-32.

Hortigüela, D. \& Pérez-Pueyo, A. (2015). Análisis de la implicación y la regulación del trabajo del alumno mediante el uso de herramientas virtuales. Revista de Comunicación Vivat Academia, 131, 82-97. doi: http://dx.doi.org/10.15178/va.2015.131.82-97.

Hortigüela, D., Pérez Pueyo, A. y Abella, V. (2015b). Perspectiva del alumnado sobre la evaluación tradicional y la evaluación formativa. Contraste de grupos en las mismas asignaturas. REICE. Revista Iberoamericana sobre Calidad, Eficacia y Cambio en Educación, 13(1), 35-48.

Hortigüela, D., Pérez-Pueyo, A., \& López-Pastor, V.M. (2015). Implicación y regulación del trabajo del alumnado en los sistemas de evaluación formativa en educación superior. Relieve: revista electrónica de investigación y evaluación educativa, 21(1), 1-5. doi: 10.7203/relieve.21.1.5171.

Hortigüela, D., \& Pérez-Pueyo, A. (2016a). Influencia de la regulación del trabajo del alumnado universitario en la implicación hacia las tareas. Psychology, Society \& Education, 8(1), 39-51.

Hortigüela, D., \& Pérez-Pueyo, A. (2016b). La evaluación entre iguales como herramienta para la mejora de la práctica docente. Revista Opción, 32(7), 865-879. 
Hortigüela, D., \& Pérez-Pueyo, A. (2016c). Percepción del alumnado de las clases de educación física en relación con otras asignaturas. Apunts. Educación Física y deportes, 123(1), 44-52. doi: http://dx.doi.org/10.5672/apunts.2014-0983.es.(2016/1).123.05.

Hortigüela, D., Abella, V., Delgado, V. \& Ausín, V. (2016). Influencia del sistema de evaluación empleado en la percepción del alumno sobre su aprendizaje y las competencias docentes. Infancia, Educación y Aprendizaje, 2(1), 20-42.

Huber, G. L. (2008). Aprendizaje activo y metodologías educativas. Revista de Educación, número extraordinario, 59-81.

Kelly, G. (2012). Lecture attendance rates at university and related factors. Journal of Further and Higher Education, 36(1), 17-40.

Kinne, L. J., Hasenbank, J. F., \& Coffey, D. (2014). Are we there yet? using rubrics to support

progress toward proficiency and model formative assessment. AILACTE Journal, 11(1), 109128.

López-Pastor, V. M., Castejón, J., Sicilia, A., Navarro, V., \& Webb, G. (2011). The process of creating a cross-university network for formative and shared assessment in higher education in Spain and its potential applications. Innovations in Education and Teaching International, 48(1), 79-90.

Lorente, E., \& Kirk, D. (2013). Alternative democratic assessment in PETE: An action-research study exploring risks, challenges and solutions. Sport, Education and Society, 18(1), 77-96.

Millis, B. (2010). Cooperative learning in higher education: Across the disciplines, across the academy. Sterling, VA: Stylus Publishing.

Mulongo, G. (2013). Effect of active learning teaching methodology on learner participation. Journal of Education and Practice, 4(4), 157-168.

Palacios, A., \& López-Pastor, V. M. (2013). Haz lo que yo digo pero no lo que yo hago: sistemas de evaluación del alumnado en la formación inicial del profesorado. Revista de Educación, 361, 279-305.

Sadler, D. R. (2010). Beyond feedback: developing student capability in complex appraisal. Assessment and Evaluation in Higher Education, 35(5), 535-550.

Shen, B., McCaughtry, N., Martin, F., \& Fahlman, N. (2009). Effects of teacher autonomy support and students' autonomous motivation on learning in Physical Education. Research Quarterly for Exercise and Sport, 80(1), 44-53.

Schunk, D. H., \& Zimmerman, B. J. (2008). Motivation and self-regulated learning: Theory, research, and applications. Mahwah, NJ: Erlbaum.

Siebert, S. \& Walsh, A. (2013). Reflection in Work-Based Learning: Self-Regulation or SelfLiberation? Teaching in Higher Education, 18(2), 167-178.

Stephens, K., \& Winterbottom, M. (2010). Using a learning log to support students' learning in biology lessons. Journal of Biological Education, 44(2), 72-80.

Stockdale, S. L., \& Brockett, R. G. (2011). Development of the PRO-SDLS: A Measure of SelfDirection in Learning Based on the Personal Responsibility Orientation Model. Adult Education Quarterly: A Journal of Research and Theory, 61(2), 161-180.

Struyven, K., Dochy, F., \& Janssens, S. (2005). Students' perceptions about evaluation and assessment in higher education: A review. Assessment y Evaluation in Higher Education, 30(4), 325-341. 
Stull, J. C., Varnum, S. J., Ducette, J., Schiller, J., \& Bernacki, M. (2011). The many faces of formative assessment. International Journal of Teaching and Learning in Higher Education, 23(1), 30-39.

Urda, J., \& Ramocki S. P. (2015). Assessing students' performance by measured patterns of perceived strengths: Does preference make a difference? Assessment y Evaluation in Higher Education, 40(1), 33-44.

Weymer, M. (2002). Learner-centered teaching. Five key changes to practice. San Francisco: Jossey-Bass. 